\title{
Globalization Deserves Some Props
}

\author{
Cletus C. Coughlin
}

$\mathrm{T}$

he term "globalization" often is perceived in a negative light, especially during workforce reductions. However, globalization has helped spur China's and India’s economic growth over the past 25 years, significantly increasing economic well-being in these populous countries. Nevertheless, poverty remains a major problem throughout the world, particularly in developing countries.

The chart illustrates the distribution of national per capita incomes throughout the world in 1980 (black line) and 2006 (blue line). ${ }^{1}$ The vertical axis measures the natural logarithm of per capita gross domestic product (GDP) adjusted for local purchasing power, so foreign incomes are converted into U.S.-dollar equivalents. Differences between the two lines reflect the growth rates in real per capita income from 1980 to 2006. For example, the U.S. log per capita income was 10.03 in 1980 and 10.54 in 2006, reflecting 67 percent growth between the two dates. Moving from left to right on the horizontal axis, the chart ranks countries from richest to poorest. The horizontal length of a country's line segment depends on its share of the world's population. Countries with small populations are represented by proportionally short line segments. China, with approximately 20 percent of the world's population, is represented by a correspondingly long line segment.

Global economic growth has been uneven. As the chart suggests, some people have become poorer, but many more now enjoy higher incomes. China, with a compound annual growth rate of 8.6 percent (or 754 percent overall from 1980 to 2006), has led the way in boosting economic well-being for the developing world. India's annual growth rate of 4.0 percent (or 177 percent overall), while modest compared with China's, is significant because of Indiàs large population. Market-oriented reforms began in the late 1970s in China; India's liberalization process began later-in the early 1990s. China's head start allowed them to leapfrog ahead of India in per capita GDP. Perhaps because of their direct competition with China, countries that were slightly richer than China in 2006 seem to have experienced little or no growth from 1980 to 2006. Finally, the richest countries became richer; U.S. real per capita income rose at a 2.0 percent annual rate (or 67 percent overall) from 1980 to 2006.

A recent report by the Commission on Growth and Develop ment highlights five elements shared by rapidly growing countries. ${ }^{2}$ First, private individuals allocate resources through markets, rather than having government employees run industries. Second, highgrowth countries have minimal restrictions on foreign trade and investment, rather than inward-looking growth strategies. Third, successful countries have high rates of domestic saving and investment. The fourth and fifth elements are economic and political stability. Responsible and credible fiscal and monetary policy help sustain modest inflation and discourage boom-bust cycles that hinder long-term growth. Similarly, a stable political environment increases confidence that laws involving property rights and contracts will be enforced. The institutional foundations stemming from economic and political stability allow individuals to make decisions whose benefits might not be realized for many years.

Although poverty remains a major world issue, reforms and policy changes that allow private individuals and firms to participate more fully in the global marketplace help alleviate this problem in developing countries.

\begin{abstract}
${ }^{1}$ For a similar chart, see Edward E. Leamer and Peter K. Schott, "The Rich (and Poor) Keep Getting Richer," Harvard Business Review, April 2005, 83(4), p. 20. One difference, which is of minimal importance, stems from our use of exchange rates based on purchasing power parity (PPP) rather than market exchange rates.

2 See Commission on Growth and Development, The Growth Report: Strategies for Sustained Growth and Inclusive Development, 2008. The Commission, supported by the World Bank and others, consists of leading practitioners and academics involved in economic development.
\end{abstract}

\section{Per Capita Incomes Throughout the World: 1980 and 2006}

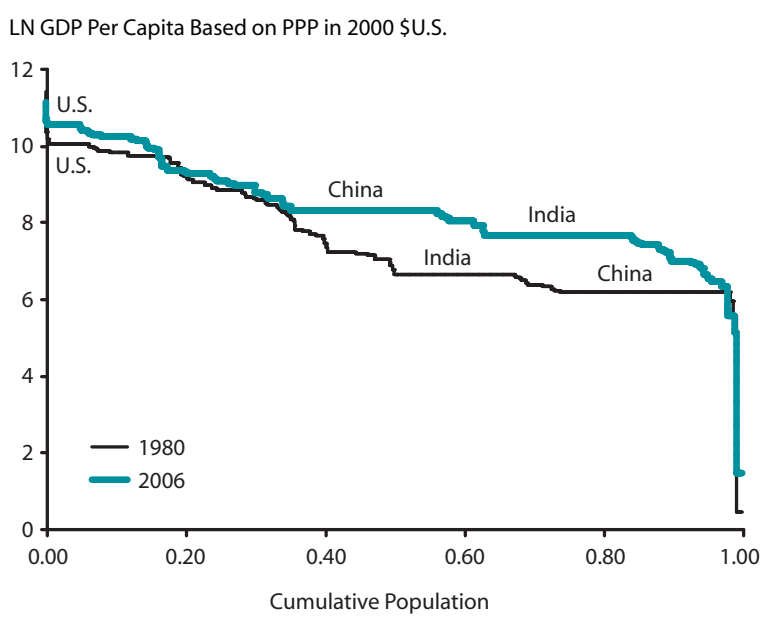

SOURCE: IMF World Economic Outlook Database, April 2008. 